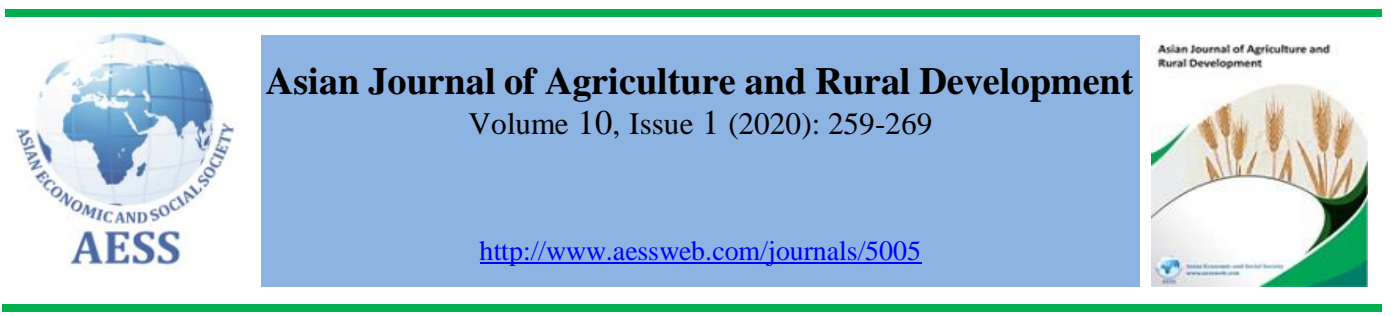

\title{
THE FAILURE OF A RURAL DEVELOPMENT PROJECT: SOUTH KOREAN OFFICIAL DEVELOPMENT ASSISTANCE IN THE DEMOCRATIC REPUBLIC OF THE CONGO
}

\author{
Hyung Baek Lim ${ }^{\text {a }}$ \\ Chulwoo Kim $^{\text {b }}$
}

\author{
${ }^{a}$ Department of International Development Cooperation, Sungkyul \\ University, South Korea
}

${ }^{\mathrm{b}}$ Department of Public Administration, Gachon University, South Korea

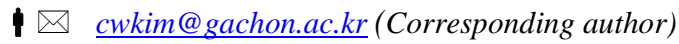

\section{ARTICLE HISTORY: \\ Received: 03-Feb-2020 \\ Accepted: 21-Apr-2020 \\ Online Available: 16-May- 2020}

\section{Keywords:}

Area study,

Democratic Republic of the Congo,

International development cooperation,

Official development assistance, Rural development

\begin{abstract}
The purpose of this study is to investigate failure factors of the official development assistance provided by South Korea for an integrated rural development project located in the village of Kitshini in the Democratic Republic of the Congo (DRC). Regional studies on the DRC were carried out on a macro level, and on the Kitshini project on a micro-level was done through literature review and participant observations. The findings indicate five inevitable exogenous variables that greatly reduced the project's efficiency, first, tribalism and tribal conflict, second, incomplete administrative organization at the local level, third, shortage of agricultural technology and agricultural market openings, four, unrealistic goals for the project, and five, the tragedy of the commons. The results suggest the necessity to conduct comprehensive research on the local area and preliminary feasibility studies to secure sufficient time to plan the project and design suitable initiatives for recipient countries and target sites.
\end{abstract}

\section{Contribution/ Originality}

The main contribution of this paper is to conduct an in-depth case that needs to be identified before performing official development assistance for the Democratic Republic of Congo. In particular, the analysis of failure factors of the integrated rural development project provides practical implications to be considered when carrying out similar projects in DRC and countries in similar circumstances in the future.

DOI: 10.18488/journal.1005/2020.10.1/1005.1.259.269

ISSN (P): 2304-1455/ISSN (E):2224-4433

How to cite: Hyung Baek Lim and Chulwoo Kim (2020). The failure of a rural development project: South Korean official development assistance in the Democratic Republic of the Congo. Asian Journal of Agriculture and Rural Development, 10(1), 259-269.

(C) 2020 Asian Economic and Social Society. All rights reserved. 


\section{INTRODUCTION}

On November 25, 2009, South Korea joined the Development Assistance Committee (DAC) of the Organisation for Economic Co-operation and Development (OECD). South Korea's official development assistance (ODA) constituted $0.31 \%$ of gross national income (GNI) in 2018. South Korea has implemented ODA in about 100 countries, but some attempts have been unsuccessful. Recent studies on ODA have revealed problems affecting South Korea's ODA. One issue is a shortage of information on recipient countries.

South Korea is the only country that has shifted from being an aid recipient to an aid donor and has no experience with colonial rule. In modern international development cooperation (IDC), most donor nations used to be colonial rulers, while recipient states tend to not have such a history. Paradoxically, South Korea may boast of being a moral nation, but there is an absolute dearth of information on recipient countries, and difficulties have arisen in IDC.

Under these circumstances, we carried out an area study of the Democratic Republic of the Congo (DRC), where South Korea is struggling substantially compared with the country's more than 100 recipient states. South Korea faces great challenges in the DRC because the latter is different in many ways, making it the toughest to deal with in terms of South Korea's development experience.

Therefore, we examined South Korea's ODA about an integrated rural development project (IRDP) in the village of Kitshini in the DRC. This initiative is a typical example of intergovernmental collaboration between South Korea and other states. We will review the DRC's observed characteristics regarding the Kitshini IRDP. It is not within our study's scope to outline all aspects of the Kitshini IRDP. ${ }^{1}$ (Thus far, very little has been done in this direction.) Rather, we intend for this paper to catalyze area studies and related interests when carrying out similar projects.

To explain the DRC's features, we must first review its history, as its current misfortunes stem from its colonial past. European states, as the ex-colonial authorities, have a moral and political responsibility for the mess they left in Africa and decolonization is still an ongoing task in many African countries (Adepoju and Adeniyi, 2019; Blaut, 1993). As the former colonial power, Belgium has a responsibility toward the DRC. The DRC was born out of the Berlin Conference (1884-1885), a global symposium held in the city of Berlin, Germany, which centered on the territorial rights of the Congo Basin, and which is sometimes referred to as the "West Africa Conference" to avoid confusion with the 1878 Berlin Conference.

Leopold Louis Philippe Marie Victor II (1835-1909), the Belgian king made the Congo river basin into a private colony in 1881. Later, when Britain joined as a latecomer, Belgium and France felt threatened, pressured Portugal, and ultimately held an international congress. Finally, Otto von Bismarck of Germany called for peaceful, honorable mediation and invited representatives to Berlin (Anstey, 1966). Fourteen countries, including the United States, the Ottoman Empire, and twelve European nations, gathered in Berlin and defined the DRC's borders. Because of this, African tribes that had never formed a modern state or had any concept of a "nation" ended up in a country called the DRC. In other words, as in most African states, the DRC was not formed as a sovereign entity by its people; hence, there was no notion of a nation-state, nor nationality. Ultimately, about 800 tribes that had clashed with each other came to belong to the government and its rules overnight. In some cases, people of the same tribe ended up belonging to different countries.

The largest beneficiary of the Berlin Conference was Belgium, which, through the Congo Basin

\footnotetext{
${ }^{1}$ Integrated rural development is a development approach that influenced rural areas in 1970s (OECD, 2016)
} 
Treaty, managed to get the intensely fought over the central African region recognized as belonging to Leopold Louis Philippe Marie Victor II. However, due to Belgium's attempts to cause disunion, until the early part of the 20th century, regional and ethnic confrontation emerged, which had never occurred before. Such discord continues in the DRC to this day.

The DRC gained independence from Belgium in 1960. From 1971 until 1997, the DRC was referred to as the Republic of Zaire and is located at the center of equatorial Africa, bordered by nine countries. Its area is the second-largest in Africa after Sudan at 905,365 square miles and the largest in sub-Saharan Africa. The DRC is the 11th biggest country in the world and most of its territory is inland, with about $40 \mathrm{~km}$ of coastlines between Cabinda, an Angola exclave, and mainland Angola. As of 2014, the population is estimated at around 82 million, and 90 million as of 2018, which makes it the fourth-biggest among African nations (Bokamba, 1976, 2019; USAID, 2020).

Table 1: An outline of the DRC's characteristics

\begin{tabular}{|c|c|c|c|}
\hline Independence & 1960 & Number of tribes & 800 \\
\hline Population & $\begin{array}{l}85,026,000 \text { (as of } 2016) \\
\text { (16th largest in the world) }\end{array}$ & Number of languages & 214 \\
\hline Size & $\begin{array}{l}2,344,858 \mathrm{~km} 2(12 \mathrm{th} \\
\text { largest in the world) }\end{array}$ & Official language & French \\
\hline $\begin{array}{l}\text { Per capita } \\
\text { income }\end{array}$ & $\$ 702.184$ (Year 2014) & $\begin{array}{l}\text { Major languages } \\
\text { besides French }\end{array}$ & $\begin{array}{l}\text { Swahili (predominant in } \\
\text { the east) Lingala } \\
\text { (predominant in the west) }\end{array}$ \\
\hline
\end{tabular}

The DRC has abundant natural resources that are incomparable to those of other countries and is in the top spot regarding the amount available for development. However, the DRC's natural resources also threaten its national stability (Shim, 2018). The DRC possesses cobalt (75\% of global reserves) and is the world's fourth-largest producer of smelting cobalt. The country also has $70-80 \%$ of the world's reserves of coltan, $10 \%$ of copper, $30 \%$ of diamonds, and around 50 types of minerals (e.g., uranium, manganese, and zinc).

These riches have caused the DRC to have the "resource curse." Various armed groups, including rebels, control the coltan mines in the east. Just as blood diamonds fueled the civil war in Sierra Leone, the DRC's natural resources drive its domestic conflict. Hence, its inhabitants deeply distrust other people and governments (Reardon et al., 2012).

In the DRC, China recently and controversially negotiated a mammoth resources-for-infrastructure deal valued at $\$ 6$ billion. In exchange for building new roads and railway lines, along with many other facilities (including hospitals, housing, and a new university), China was guaranteed a supply of copper and cobalt over a period of 20 years. Civil society critics of the deal said that by agreeing to terms like these, the DRC risked vastly underselling its assets. The Western powers and international financial institutions that have traditionally been the DRC's leading economic partners were unhappy as well (French, 2014).

\section{MATERIALS AND METHODS}

\subsection{The project site}

In the international development cooperation, a recipient country requests the development aid to a donor country. In other words, development cooperation projects are not decided unilaterally by donor countries. Instead, after requested by the recipient countries, the project will be implemented when the donor country decided to do it. 
This project requested by the DRC is an "Integrated Rural Development" in the Kitshini region. Kitshini, the closest village to the capital of Kinshasa and about $80 \mathrm{~km}$ away from it, was selected as the project site. Its main purpose was to bring agricultural products produced through the project into Kinshasa. The area for the initiative covers $30 \mathrm{~km}^{2}$. DRC suggested the site and the details of the project and South Korea decided to implement the project after conducting a preliminary feasibility study. ${ }^{2}$

From 1991 to 2015, South Korea provided 10 free aid projects; one of those was the Kitshini IRDP, the period of which was from 2013 to 2017, and the budget was 3 million dollars. The purpose was to reduce poverty and increase income by strengthening Kitshini's capacity for integrated rural development. This venture included a program to boost agricultural production and value-adding, local community capacity building, expert dispatch, and equipment support. The undertaking can fall into three major categories: (1) agricultural production; (2) the agricultural value chain; and (3) improved living conditions.

Since rebels dominate the eastern region and Kinshasa is located along the Congo River at the western end of the country, the most ideal locales for projects are near Kinshasa since it is especially safe and home to a large market, giving it an overall advantage as an IRDP site. The DRC is affected by a shortage of food and its agriculture, in the beginning, stages were inefficiently organized into lots for small families (Hanson and Leautier, 2013). This means that the DRC needed to dramatically increase its productivity to be self-sufficient in terms of food production.

There is no modern land ownership in Kitshini, which is common in traditional African societies. The village's agricultural development is not simply a question of productivity or technology. The village is typical of rural Africa. There are about 2,000 inhabitants and around 150 households. Unfortunately, the project likely benefitted fewer individuals than could be hoped for due to numerous reasons (e.g., a dearth of transportation, larger congregations of tribal residences on the project site, a lack of understanding about the enterprise, and participation).

The DRC is an agrarian country, but also a food-scarce one and hunger (Mwisha-Kasiwa, 2018), and is unable to create many sources of employment. There are few high-quality jobs. In urban zones, most available occupations involve simple labor, and in rural areas, jobs are rare; $70-80 \%$ of Kitshini's residents are short-term workers.

\subsection{Research methods}

We surveyed the relevant literature. At the macro level, we carried out regional research on DRC. At the micro-scale, we completed a regional study on the Kitshini in February 2018. Since Kitshini's inhabitants do not speak French (the country's official language), an official from the Ministry of Agriculture and Rural Development who spoke English and French, one official from the Ministry of Rural Development who spoke French and Lingala, and one a DRC native student in the Ph.D. program in Korea who spoke English, French, Lingala, and Korean joined.

Following this, we examined the project site and conducted regional research on Kitshini by reading both domestic and international monographs and papers. We identified many pieces of literature related to the Kitshini IRDP (e.g., baseline surveys; interim reports and assessments; the outcome, expert activity, and training results reports).

Through the technique of participant observation, a surveyor enters a country, lives with locals for a long time, and directly takes part in as many social situations as possible whenever the opportunity

\footnotetext{
2 The evaluation of IDC projects is used by adjusting the five principles of relevance, effectiveness, efficiency, impact, and sustainability, including the addition of some items according to the nature of the project. In the preliminary evaluation, the focus will inevitably be on relevance and sustainability (OECD DAC, 1991).
} 
arises to witness and record the actors, places, and activities (Spradley, 1980). In line with participant observation, we initially began our research with a descriptive examination covering all aspects of Kitshini. We then concentrated on the achievements of the rural development project as a form of public aid for the village. Again, we centered on selective service, which narrowed the focus to the factors that caused the undertaking to fail.

\section{RESULTS AND DISCUSSION}

The factors that caused the Kitshini IRDP to fail can be largely divided into three external and two internal elements: (1) tribalism and tribal conflict; (2) incomplete administrative organization at the local level; (3) shortage of agricultural technology and agricultural market openings; (4) unrealistic goals for the project; and (5) the tragedy of the commons.

\subsection{Tribalism and tribal conflict}

The DRC is home to around 800 tribes and has been subject to constant civil strife due to the resource curse mentioned earlier. Western nations, as well as Rwanda and Uganda, have their eyes on the DRC's resources and encourage hostilities. A civil war is ongoing in the region of Kivu, which contains coltan. Rebel forces currently occupy the area; they sell coltan at a low price to neighboring countries, such as Rwanda, and buy weapons with the profits. Rwanda in turning exports coltan for a hefty sum. An average of 1,000 people dies every day from civil unrest.

Today, tribal members rarely consider themselves to be citizens. Rather, individuals feel a greater sense of belonging to their tribes than to the country. As such, the Western - or modern - the concept of a "nation" is rather weak. Hence, the DRC should not be perceived from the perspective of Western nationalism (Bokamba, 2008).

With numerous ethnic groups, the DRC is a multilingual nation with 214 languages, including French, the official language of communication, as the DRC was once a Belgian colony. Major groups in city centers use Lebanese Arabic. Non-native tongues such as English, Greek, Hindi, and Portuguese can be heard as well. Kiswahili is commonly used in the east, while Lingala is mostly preferred in the west (Ethnologue, 2005).

The Teke tribe, which speaks Lingala, is the majority group in Kitshini; there are two minority tribes. The village's three tribes cannot speak French or English. Thus, outsiders cannot talk to them without an interpreter. This causes problems in terms of communication between the government and these tribes, which also suffer from conflict and struggles for leadership (Anyu and Ayaba, 2017).

The three most important individuals in the village are the chieftain, Nda Iyebe Beatrice; the farmers' cooperative union leader, Issac Dimanu; and the former farmers' cooperative union leader, Gimeya Rodolphe. The deceased Mamadou chieftain and his younger sister Beatrice, the current chieftain, belong to the Teke tribe. Dimanu belongs to the second-largest tribe, while Rodolphe belongs to the third largest tribe. Each tribe's members feel a strong sense of belonging and are not friendly with members of other groups. These circumstances negatively affected Kitshini IRDP.

\subsection{Incomplete administrative organization at the local level}

The Kitshini IRDP is closely linked to the DRC's national and rural development policies. Through increased agricultural productivity and subsequent agricultural sales (both of which could help to solve the food shortage), the project was intended to directly increase incomes in Kitshini. However, the DRC is not fully equipped in terms of an administrative organization; therefore, the central government's administrative power does not influence rural villages. The DRC also lacks finances. Hence, government officials are often not paid enough or do not receive their wages, 
making civil servants' capacity quite inadequate at both the central and local government levels. There are many civil servants in proportion to the public, but in numerous regions, especially in rural areas, civil servants and local governments are unable to perform their duties properly.

Moreover, when new ministers are needed, those with connections appoint some of "their own" people to the positions, causing the status of public officials to be unstable and unprofessional. As a result, in rural zones without local administrative organization, the traditional tribal system becomes responsible for it, and the patriarchs or chieftains of each tribe oversee local affairs as a part of informal operations. This is the case in Kitshini, where the village's three tribes live according to their customs.

The DRC's economy grew by $8.5 \%$ in 2013 and $9.0 \%$ in 2014; these percentages were the some of the highest since the DRC gained independence from Belgium, but because of the country's heavy reliance on exporting natural resources, its economic growth declined with the weakening of global commodity prices to (the estimated rates of) $6.9 \%$ in $2015,3.9 \%$ in 2016 , and $4.3 \%$ in 2017 . The DRC's GNI is less than $\$ 300$, and per capita income was about $\$ 700$ annually as of 2016 . In the 1990s, two civil wars largely destroyed the clothing industry, which led to foreign clothing import/distribution companies to be $70 \%$ Lebanese-owned.

The DRC is an agrarian nation with no other major industries; $70 \%$ of the population works in the farming sector, but without adequate skills. There is also a dearth of drinking and farming water. The development of rural zones is therefore considered a nationwide task.

Since human resource development is a key factor for poverty alleviation (Moyar, 2016), the Kitshini IRDP included the construction of an elementary school. After it builds, desks and chairs were provided. The students were highly satisfied with the school, and the rate of absences fell to a great extent. However, these changes had nothing to do with qualitative innovation in education. Since the DRC fails to pay teachers their salaries, teachers visit each family after school and collect tuition independently; this lowers the standard of education. The curriculum is important in elementary schools, and teachers should be able to serve as caretakers, but unfortunately, this is not the case.

The rural population is spilling into urban zones due to the underdevelopment of agriculture in rural regions. Like other developing countries, the DRC has more civil servants than necessary, and when the regime or cabinet changes, current civil servants are asked to leave their posts. Highranking officials replace them with members of their tribes, resulting in poor continuity of work and a lack of expertise.

\subsection{A shortage of agricultural technology and agricultural market openings}

Regarding crop cultivation, the DRC suffers from famines. The circumstances are no different in Kitshini. Figure 1 shows the market supply and market demand curves together. They intersect at a certain point that marks the market's equilibrium. The price at this intersection is called the equilibrium price, and the amount is called the equilibrium quantity (Mankiw, 2012).

The DRC faces a supply shortage of agricultural products (the point of contact between $\mathrm{P}$ and $\mathrm{Q}$ in Figure 1). As such, up to the point of balance between supply and demand for agricultural products (the point of contact between P1 and Q1 in Figure 1), their increased manufacturing will not lower agricultural prices. 


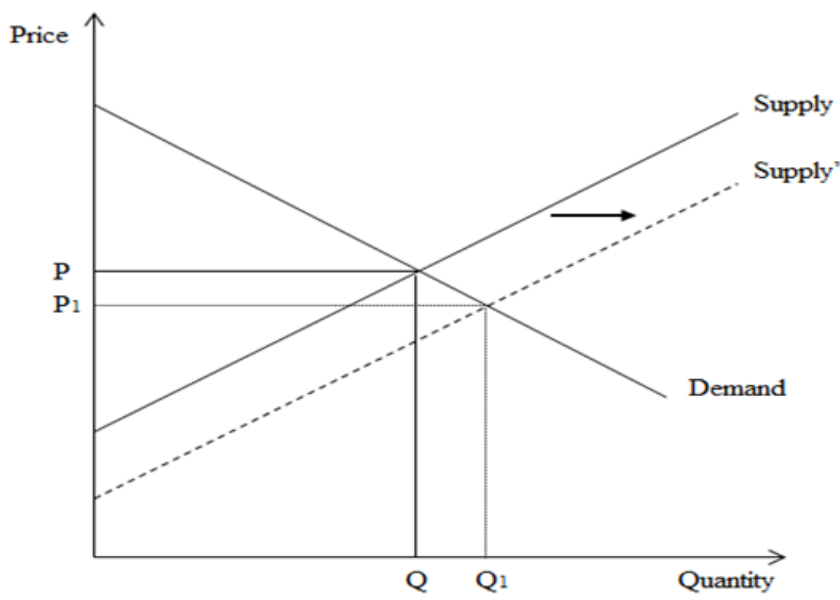

Figure 1: The supply-demand curve

The villagers of Kitshini remain self-sufficient, primarily by cultivating the cassava shrub. In addition to cassava, they mostly grow sweet potatoes and peanuts. Bread made from cassava and sweet potatoes is their staple, even if production is increased. Hence, it is necessary to raise the productivity of edible crops (such as cassava) to preserve and boost their self-sufficiency. However, because the market price of cassava is low, it does not contribute substantially to raising farmers' incomes. Thus, many farmers want to grow more lucrative crops.

The demand for agricultural products exceeds the supply in the DRC's domestic market. If there are no market openings, with too many buyers chasing too few agricultural products, suppliers can take advantage of shortages by hiking up prices. DRC's agricultural market has already opened, and agricultural products (including lucrative crops) have been imported. Figure 2 shows agricultural market openings and prices, demonstrating that the overall market price of imported agricultural products is below the equilibrium price. Hence, consumers can purchase imported agricultural products at cheaper prices (P1) than the equilibrium price (P). Moreover, the number of agricultural products demanded (Q1) exceeds the number of agricultural products supplied (Q). The interval from Q to Q1 represents the country's market share of imported agricultural products, for which the price and quality are competitive. The flood of cheap, imported agricultural products threatens the DRC's farmers and agricultural development. The government has no alternative policies to mitigate these circumstances.

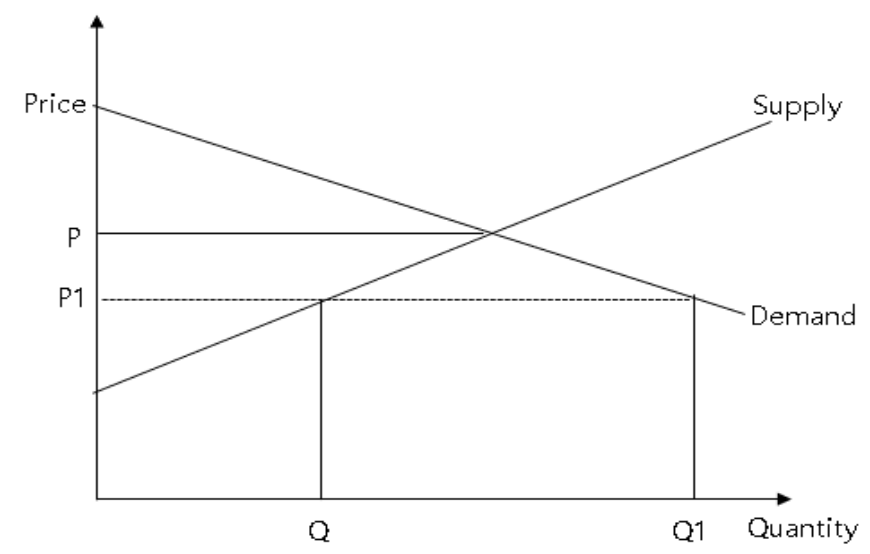

Figure 2: Agricultural market openings in the DRC 


\subsection{Unrealistic goals for the project}

The Kitshini IRDP's overarching goal is to increase incomes from the processing of surplus agricultural products, which should result from better agricultural productivity thanks to the project. A processing plant (i.e., factory) was meant to augment the added value of agriculture. This idea is based on the value chain theory (Porter, 1985), an analytical management technique that helps one to understand a company's core competencies as a combined form of organizational capability. Companies often use the value chain as a model to identify their standing in their industry's landscape and to find areas where they can enhance their competitiveness. To do so, they examine how business processes can be improved so that there is greater value to be gained at each stage of the value chain.

As for agriculture, the value chain generally goes through the phases of production $\rightarrow$ manufacturing $\rightarrow$ logistics $\rightarrow$ sales $\rightarrow$ services. The "agricultural value chain" refers to all activities carried out by various stakeholders, from the procurement of raw materials to final consumption. "Activities" include agricultural products, as well as all services rendered/used and the entire flow of information involved in sales. Analysis of the agricultural value chain entails ascertaining the extra value generated by moving along the chain's stages; it is an extended concept of supply chain analysis, which was commonly used in the past. We employed the term "value chain" instead of "supply chain" because the additional value is created when agricultural products move along the supply chain. The value chain is being actively promoted in Korean agriculture but poses a challenge that only some Korean farmers have been able to resolve.

Let us simplify the agricultural value chain. Although it was theoretically possible to demand a combination of secondary (processing and logistics) and tertiary (services) stages (according to the value chain concept) from the DRC's farmers, who are still in the early stages (agricultural production) of agro-industrialization, this was not suitable and hence unrealistic. Kitshini's farmers are still in the production stage; they lack management abilities as well as agricultural technology and are not equipped to handle secondary (e.g., processing, distribution) or tertiary industries.

The more direct problem is the DRC's capacity to supply electricity. The processing plant could not be operated initially because the electricity promised by the DRC was not provided. Machines were abandoned, leaving only oil-operated emergency generators to run. Unrealistic goals were set for the Kitshini IRDP, which skewed the allocation of resources. Narrowing the project scope and testing it out on a smaller scale in a trial/demonstration village would lead to clearer outcomes. By doing so, the village's residents would be able to build their skills; it would then be ideal to enlarge/expand the project to greater scope and complexity.

\subsection{The tragedy of the commons}

As for farming equipment, the government provided a tractor, which the farmers' cooperative union operated. Within the union, there was a tractor operation team and a truck operation team that generate income, so Kitshini's farmers naturally want to work in these groups. However, at present, the tractor is broken. It takes apart and abandoned. The original plan was to increase crop production by developing agricultural technology and to use trucks to transport 20 tons of the yielded crops four times a month, but now, there is no production of agricultural products to sell on the market.

The truck was also left unattended, and its battery was taken out and used for solar power. There are solar power panels in front of the town hall, and the electricity produced there is charged into batteries. This has improved living conditions. There are five batteries in parallel at the town hall; they are charged via a single battery connected to the solar panels. The resulting electricity fuel the television in the control tower. Since battery life is only about 3-5 years, there is a risk that solar power production will end in the future. 
Income distribution among Kitshini's residents is unstructured and unclear. There is no concept of a joint cost burden for maintenance and repairs. Currently, all projects have been halted, no income is created, and there is no profit to pay for public expenses. Since the tractor and trucks are considered public rather than private goods, there is a high risk of the "tragedy of the commons" due to externalities. Maintenance was not considered before the Kitshini IRDP began. Unfortunately, the DRC's farmers lack the money for repairs, as well as a sense of modern economics.

Micro credits are responsible for agricultural funding in the farmers' cooperative union. For microcredits, the union brought in a safe by spending $\$ 150$ on a truck for transport. The safe was placed in the village's office. Rodolphe, the former (second) union leader, placed a local woman in charge of keeping track of the books in Lingala, but ever since Dimanu was inaugurated as the third (present) union leader, the woman has become untraceable.

The truck is not operating, leading to no sales of vegetables in Kinshasa, and all livestock (poultry and pigs) are gone, meaning there have been no microcredit loans. There is a mere $\$ 600$ balance for microcredits; no villagers can maintain the books. In theory, loans are given to farmers who own farms that contribute to livestock and agricultural business, but the loans have virtually stopped.

The positive aspects of microfinance are well known due to the influence of Bangladesh's Grameen Bank and founder Yunus' Nobel Peace Prize. But there are also studies of adverse outcomes in African countries (Mannah-Blankson, 2018; Nanziri, 2016; Sinclair, 2012). Even the case of Grameen Bank of Bangladesh, which is famous for its microcredits, it would be stretching the truth to say that the bank has been wholly successful. Unlike regular banks, which require collateral and guarantees, Grameen was originally meant to be a bank for the poor; it is characterized by trustbased loans, microloans, five-member schemes (which are different from joint liability based on a guarantee), and providing services whereby visits are paid to rural areas. Of their loans, $97 \%$ are given to women. However, the bank has been severely criticized for raking in profits from capitalism and deepening the vicious cycle of poverty by forcing poor women to repay their debts. Unlike how it may seem on the surface, the bank is obsessed with turning a profit. The bank is under scrutiny for exploiting people's honor, a value that is very important in Bengali culture. The bank's tactics have caused deep cracks in terms of family and community solidarity (Karim, 2011).

\section{CONCLUSIONS}

From the outset, the Kitshini IRDP was accompanied by an insufficient regional exploration of the DRC, a nation completely unlike South Korea. As a result, inevitable exogenous variables greatly reduced the project's efficiency because those who devised the original scheme did not grasp the attributes of local tribes and their circumstances during the planning stage. The Korea International Cooperation Agency (KOICA) was the project management consulting firm chosen to implement the project. KOICA has a lot of experience in overseas business, but its understanding of the DRC and Kitshini was far from adequate. However, it was impossible for KOICA to fully identify the village's characteristics based on such a short timeline. Moreover, even the DRC's Ministry of Rural Development did understand the village's features and needs.

Crops, poultry, pigs, and the processing plant have already ceased to operate and are thus not sustainable. Thus, the focus should shift to future maintenance and repairs. Drinking water is highly sustainable, as is the elementary school, but low educational standards are a problem, and a strategy to link enrollment rates to middle/high schools needs to be developed. Tractors and trucks are classified as common goods, so externalities and the tragedy of the commons occur. Hence, for sustainability, externalities should be eliminated, and mechanisms to preserve and fix things need to be established. 
It was necessary to thoroughly investigate the competencies of Kitshini and the Ministry of Rural Development; these abilities were overestimated from the start, as the project was beyond their capacity. This ultimately led to many difficulties. It is necessary to conduct comprehensive research on the local area and preliminary feasibility studies to secure enough time to plan the project and design suitable initiatives for recipient countries and target sites. Relationships with business partners, in addition to governance between project partners and residents, need to be firmly in place. It takes considerable time to establish governance. At the same time, it is vital to prevent conflicts between modern and traditional practices. Recipient countries demonstrate the effects that South Korea once experienced, further underscoring the need for more time.

Ironically, colonial studies re-emerged in Britain after World War II in the name of development research (Jessica, 2018). In Britain, where colonization was at its peak in the 1950s and 1960s, most colonies, including African ones, became independent (KOICA, 2016). Although formerly colonizing countries are morally criticized, they tend to be more familiar with recipient states than South Korea, which does not have the same history. Paradoxically, South Korea is moral but lacks the knowledge and experience of the former colonial power, as well as those of aid recipients. Moreover, since joining the OECD's DAC in 2009, South Korea's history of IDC has been brief; therefore, South Korea needs to do more of an effort than developed nations to carry it out (Lim, 2018).

By examining the Kitshini IRDP, lessons were learned for future ODA projects; the purpose was to improve the "development effectiveness" of South Korea's ODA. The point is that donor nations should better understand recipient countries. The importance of area studies cannot be overemphasized. It is necessary to have an in-depth comprehension of the situation on the ground and the recipient state's unique traits, as well as at the project site. For this reason, adequate area/regional and preliminary feasibility research should be carried out (Lim, 2016).

Funding: This study did not receive any specific financial support.

Competing Interests: The authors declared that they have no conflict of interests.

Contributors/Acknowledgement: All authors participated equally in designing and estimation of current research.

Views and opinions expressed in this study are the views and opinions of the authors, Asian Journal of Agriculture and Rural Development shall not be responsible or answerable for any loss, damage or liability, etc. caused in relation to/arising out of the use of the content.

\section{References}

Adepoju, A. T., \& Adeniyi, S. B. (2019). The State and crisis of citizenship in contemporary Africa: revisiting the globalization thesis research. African Journal of Democracy and Governance, 6(2-3), 202-226.

Anstey, R. (1966). King Leopold's legacy. London: Oxford University Press.

Anyu, J. N., \& Ayaba, M. N. (2017). Leadership failure and the tragedy in the Democratic Republic of the Congo. International Journal of Social Science and Economic Research, 2(9), 46694686.

Blaut, J. M. (1993). The colonizer's model of the world. London: The Guilford Press.

Bokamba, E. G. (1976). Authenticity and the choice of a national language: the case of Zaire. Présence Africaine, 99-100(3), 104-142.

Bokamba, E. G. (2008). D. R. Congo: Language and 'authentic nationalism. in Andrew Simpson, (ed.), Language and National Identity in Africa. London: Oxford University Press: 214234.

Bokamba, E. G. (2019). Nationalism and the emergence of Lingala as a supranational language in DR Congo. World Englishes, 38(3), 53-66.

Ethnologue. (2005). Language maps of Democratic Republic of the Congo. www.ethnologue.com. 
French, H. W. (2014). China's second continent: how a million migrants are building a new empire in Africa. New York: Vintage Books. USA

Hanson, K. T., \& Leautier, F. (2013). Jobless economic growth in Africa: is there a role for agriculture?. Journal of African Development, 15(2), 1-17.

Jessica, J. (2018). Anthropology and the Study of Africa. In Oxford Research Encyclopedia of African History. New York: Oxford University Press.

Karim, L. (2011). Microfinance and Its Discontents: women in debt in Bangladesh. Minneapolis and London: University of Minnesota Press.

KOICA (2016). Development Studies. Korea: Prunsoop Books.

Lim, H. B. (2016). Study on international development cooperation using area studies. The Journal of Korean Policy Studies, 16(3), 19-41.

Lim, H. B. (2018). The Interdisciplinarity for international development assistance: focused on area study, economics, planning, international rural extension. Journal of the Korean Regional Development Association, 30(1), 121-150.

Mankiw, N. G. (2012). Principles of Economics (7th ed.). Seoul: CENGAGE Learning.

Mannah-Blankson, T. (2018). Gender Inequality and Access to Microfinance: Evidence from Ghana. Journal of African Development, 20(2), 21-34.

Moyar, M. (2016). Aid for elites: building partner nations and ending poverty through human capital. UK: Cambridge University Press.

Mwisha-Kasiwa, J. (2018). Household economic well-being and child health in the democratic republic of Congo. Journal of African Development, 20(1), 48-58.

Nanziri, E. L. (2016). Financial inclusion and welfare in South Africa: Is there a gender gap?, Journal of African Development, 18(2), 109-134.

OECD DAC (1991). Principles for evaluation of development assistance. Paris: OECD DAC.

OECD (2016). A new rural development paradigm for the $21^{\text {st }}$ Century. Paris: OECD.

Porter, M. E. (1985). Competitive Advantage. New York: Free Press. USA

Reardon, M. K., Jensby, M. N., Boesen, J., Tian, M., \& Malinak, S. (2012). Aid effectiveness in the democratic republic of Congo: a case study investigating the factors influencing ineffective Aid. The Interdisciplinary Journal of International Studies, 8(1), 59-73.

Shim, J. Y. (2018). The History of Democratic Republic of the Congo. Korea: Adinkra Books.

Sinclair, H. (2012). Confessions of a Microfinance Heretic: How Microlending Lost Its Way and Betrayed Poor. San Francisco: Berrett-Koehler Publishers.

Spradley, J. P. (1980). Participant Observation. New York: Rinehart and Winston.

USAID (2020). Democratic Republic of the Congo. Retrieved from www.usaid.gov/democraticrepublic-congo. 